\title{
ULKUS KRONIS: MENGENALI ULKUS DEKUBITUS DAN ULKUS DIABETIKUM
}

\author{
Lalu Muhammad Hafizh Izuddin Alzamani, Mona Rianta Yolanda Marbun, \\ Mutya Eka Purwanti, Rani Salsabilla, Siti Rahmah \\ Fakultas Kedokteran, Universitas Mataram, Indonesia \\ Email: laluhafiz88@gmail.com, monariantayolanda29@gmail.com, \\ mutyaekapurwanti@gmail.com, ranisalsabilla20@gmail.com, \\ sitirahmah2701@gmail.com
}

\begin{abstract}
Abstrak
Ulkus kronis merupakan penyebab utama morbiditas dan mortalitas dengan prevalensi yang meningkat. Penyebab dari ulkus kronis yaitu disfungsi vena, diabetes mellitus, infeksi, neuropati perifer, tekanan, dan aterosklerosis. Ulkus dekubitus disebabkan oleh tekanan mekanis yang tidak dapat dihilangkan ke jaringan lunak, biasanya terjadi pada tulang yang menonjol. Selain itu, adapun ulkus diabetikum merupakan salah satu komplikasi diabetes melitus yang menyebabkan peningkatan morbiditas secara keseluruhan pada pasien. Pada ulkus diabetikum dapat terbentuk karena kurang nya kontrol glikemik, neuropati, penyakit pembuluh darah tepi, atau perawatan luka pada kaki yang tidak maksimal. Artikel ini bertujuan untuk meninjau ulkus kronis, khususnys ulkus decubitus dan ulkus diabetikum. Pencarian sumber dilakukan di portal online publikasi jurnal seperti Google Scholar, dan NCBI dengan kata kunci "Ulkus kronis, TIME". Secara global, insiden ulkus dekubitus mencapai 33\% dan ulkus diabetikum mencapai $15 \%$ dari keseluruhan penderita diabetes. Dalam menangani ulkus kronik, secara umum terdapat prinsip dasar yaitu TIME. Akronim TIME adalah singkatan dari 4 hal yang perlu diperhatikan, yaitu : $\mathrm{T}$ (Tissue) untuk jaringan yang tidak layak atau sudah tidak baik; I (Infection) untuk luka yang terdapat infeksi/inflamasi; $M$ (Moisture) untuk ketidakseimbangan kelembaban luka, yang harus ditangani; E (Edge) untuk luka yang tepi nya tidak tidak melintasi ke luka.
\end{abstract}

Kata kunci: Ulkus Kronis, Ulkus Dekubitus, Ulkus Diabetikum, TIME

\section{Abstract}

Chronic ulcers become the factors of morbidity and mortality with an increasing prevalence. The causes of chronic ulcers are venous dysfunction, diabetes mellitus, infection, peripheral neuropathy, stress, and atherosclerosis. Decubitus ulcers are caused by irreversible mechanical pressure on the soft tissue, usually on prominent bones. In addition, the diabetic ulcer is a complication of diabetes mellitus that causes an increase in overall morbidity in patients. Diabetic ulcers can form due to a lack of glycemic control, neuropathy, peripheral vascular disease, or inadequate treatment of wounds on the feet. This article aims to review Chronic Ulcers, specifically Decubitus Ulcers, and Diabeticum Ulcers.

Copyright holder: Lalu Muhammad Hafizh Izuddin Alzamani, Mona Rianta Yolanda Marbun, Mutya Eka Purwanti, Rani Salsabilla, Siti Rahmah (2022) 
Source searches were carried out on online portals for journal publications such as Google Scholar (scholar.google.com) and NCBI (ncbi.nlm.nih.gov), with the keyword "Chronic Ulcers, TIME. Globally, the incidence of pressure ulcers reaches $33 \%$ and diabetic ulcers reach $15 \%$ of all diabetics. In dealing with chronic ulcers, in general, there is the main principle, namely TIME. The acronym TIME stands for four things to pay attention to, namely: T (Tissue) for a wound that is not feasible or deficient; I (Infection) for with infection/inflammation; $M$ (Moisture) for wound moisture imbalance, which have to be corrected; E (Edge) for a wound where the edge does not cross into it.

Keywords: Chronic Ulcers, Decubitus Ulcers, Diabeticum Ulcers.

Diserahkan: 02-01-2022Ｄiterima: 25-01-2022Ｄiterbitkan: 20-02-2022

\section{Pendahuluan}

Ulkus kronis merupakan penyebab utama morbiditas dan mortalitas dengan prevalensi yang meningkat. Dewasa ini, peningkatan prevalensi ulkus kronis sebagian karena populasi yang menua dan peningkatan faktor risiko seperti diabetes dan obesitas. Ulkus kronis disebabkan oleh berbagai penyakit termasuk disfungsi vena, diabetes mellitus, infeksi, neuropati perifer, tekanan, dan aterosklerosis. Ulkus kronis dapat diartikan sebagai gangguan jaringan kulit yang membutuhkan waktu lebih dari enam minggu untuk sembuh (Busch el al., 2017).

Ulkus dekubitus dan ulkus diabetikum merupakan ulkus kronis yang disebabkan oleh tekanan dan diabetes melitus. Ulkus dekubitus adalah luka pada kulit atau jaringan lunak yang terbentuk karena tekanan berkepanjangan pada area tubuh tertentu (Zaidi dan Sharma, 2021). Sedangkan ulkus diabetikum adalah salah satu komplikasi diabetes melitus yang menyebabkan peningkatan morbiditas secara keseluruhan pada pasien. Penderita diabetes melitus (tipe 1 atau 2) memiliki risiko seumur hidup mengalami komplikasi ulkus diabetikum sebesar 25\% (Packer et al., 2021).

Secara global, ulkus dekubitus merupakan penyebab utama dari morbiditas dan mortalitas di pelayanan kesehatan. Hal ini menjadikan ulkus dekubitus masalah besar di dunia kesehatan. Ulkus dekubitus bisa terjadi pada beberapa ribu orang setiap tahun. Terapi yang dibutuhkan juga menelan biaya cukup tinggi setiap tahunnya, sehingga membebani ekonomi kesehatan yang sudah langka. Pasien dengan ulkus dekubitus harus menerima perawatan segera, karena jika tidak, komplikasi yang terjadi bisa berakibat fatal (Zaidi dan Sharma, 2021).

Pada penderita diabetes melitus, ulkus diabetikum dapat dicegah untuk terjadi. Hal ini dikarenakan faktor pemicu paling sering terjadinya ulkus diabetikum adalah trauma ringan (Packer et al., 2021). Saat ini, terapi standar untuk ulkus kronik, baik itu ulkus decubitus maupun ulkus diabetikum meliputi kompresi, debridement dengan pembedahan, pengendalian infeksi, dan pembalut luka yang memadai (Busch el al., 2017). 
Lalu Muhammad Hafizh Izuddin Alzamani, Mona Rianta Yolanda Marbun, Mutya Eka Purwanti, Rani Salsabilla, Siti Rahmah

\section{Metode Penelitian}

Penulisan artikel ini menggunakan berbagai jenis sumber yang berasal dari jurnal ilmiah. Pencarian sumber dilakukan di portal online publikasi jurnal seperti National Center for Biotechnology Information / NCBI (ncbi.nlm.nih.gov) dan Google Scholar (scholar.google.com). Kata kunci yang digunakan "Ulkus Kronis, Ulkus Dekubitus, Ulkus Diabetikum, TIME”.

\section{Hasil dan Pembahasan}

\section{Ulkus Dekubitus}

\section{Definisi, Epidemiologi dan Etiologi Ulkus Dekubitus}

Ulkus dekubitus adalah luka pada kulit dan jaringan lunak yang terbentuk karena tekanan yang terus menerus atau dalam waktu yang lama pada kulit. Ulkus ini dapat terjadi di area tulang tubuh seperti iskium, trokanter mayor, sakrum, tumit, malleolus (lateral daripada medial) dan oksiput. Lesi ini sebagian besar terjadi pada orang yang mobilitasnya menurun sehingga sulit dalam mengubah posisi tubuhnya (Zaidi dan Sharma, 2021).

Secara global, insiden ulkus dekubitus mencapai 33\%. Hal ini menyebabkan ulkus dekubitus menjadi masalah besar di pusat pelayanan kesehatan akut maupun kronik. Perawatan dalam ruang intensif meningkatkan risiko terjadinya ulkus dekubitus, dilaporkan insidennya mencapai 33\% dan prevalensi $41 \%$. Ulkus dekubitus umumnya terjadi pada 2 minggu pertama perawatan di rumah sakit, dan pada pasien yang mengalami ulkus, 54\% timbul setelah masuk rumah sakit (Pranarka, 2015). Pasien usia lanjut lebih rentan terhadap ulkus decubitus, dimana dua pertiga dari ulkus terjadi pada pasien yang berusia di atas 70 tahun.

Perkembangan ulkus dekubitus kompleks dan multifaktorial. Penyebab utamanya yaitu karena hilangnya persepsi sensorik, gangguan kesadaran lokal dan umum, bersama dengan penurunan mobilitas, kondisi tersebut membuat pasien tidak menyadari ketidaknyamanan sehingga tidak mengurangi tekanan yang terjadi. Ulkus dekubitus dapat terjadi karena di sebabkan oleh faktor eksternal (tekanan, gesekan, gaya geser dan kelembapan) dan faktor internal (demam, malnutrisi, anemia, dan disfungsi endotel) (Zaidi dan Sharma, 2021). Adapun beberapa kondisi yang mempengaruhi terbentuknya ulkus dekubitus, diantaranya yaitu:

a. Imobilitas: Pada pasien yang tidak bergerak minimal dua jam terbaring di tempat tidur, maka hal tersebut dapat terbentuk dasar dari ulkus dekubitus.

b. Disfungsi mekanisme pengaturan saraf: bagian tersebut bertanggung jawab untuk pengaturan aliran darah lokal, apabila terjadi disfungsi maka dapat terbentuk ulkus.

c. Tekanan yang berkepanjangan: Apabila terjadi tekanan yang lama pada jaringan, dapat menyebabkan oklusi kapiler sehingga tingkat oksigen 
menjadi rendah di daerah tersebut, jaringan iskemik mulai menumpuk metabolit beracun, kemudian terbentuk ulserasi jaringan dan nekrosis.

d. Pada beberapa kondisi berikut dapat terjadi kecenderungan untuk mengalami ulkus decubitus, yaitu pasien dengan penyakit neurologis, penyakit kardionvaskular, anestesi berkepanjangan, dehidrasi, malnutrisi, hipotensi dan pasien bedah.

\section{Patofisiologi Ulkus Dekubitus}

Ulkus dekubitus dapat disebabkan oleh banyak faktor (faktor eksternal dan internal), akan tetapi hampir semua akan menunjukan gejala yaitu terjadinya iskemia dan nekrosis. Ulkus decubitus disebabkan oleh tekanan mekanis yang tidak dapat dihilangkan ke jaringan lunak, paling sering terjadi pada tulang yang menonjol seperti sakrum, iskium, tumit, atau trokanter. Hal ini dapat dilihat pada lokasi ulkus yang sering terbentuk akibat tekanan, sebagai berikut:

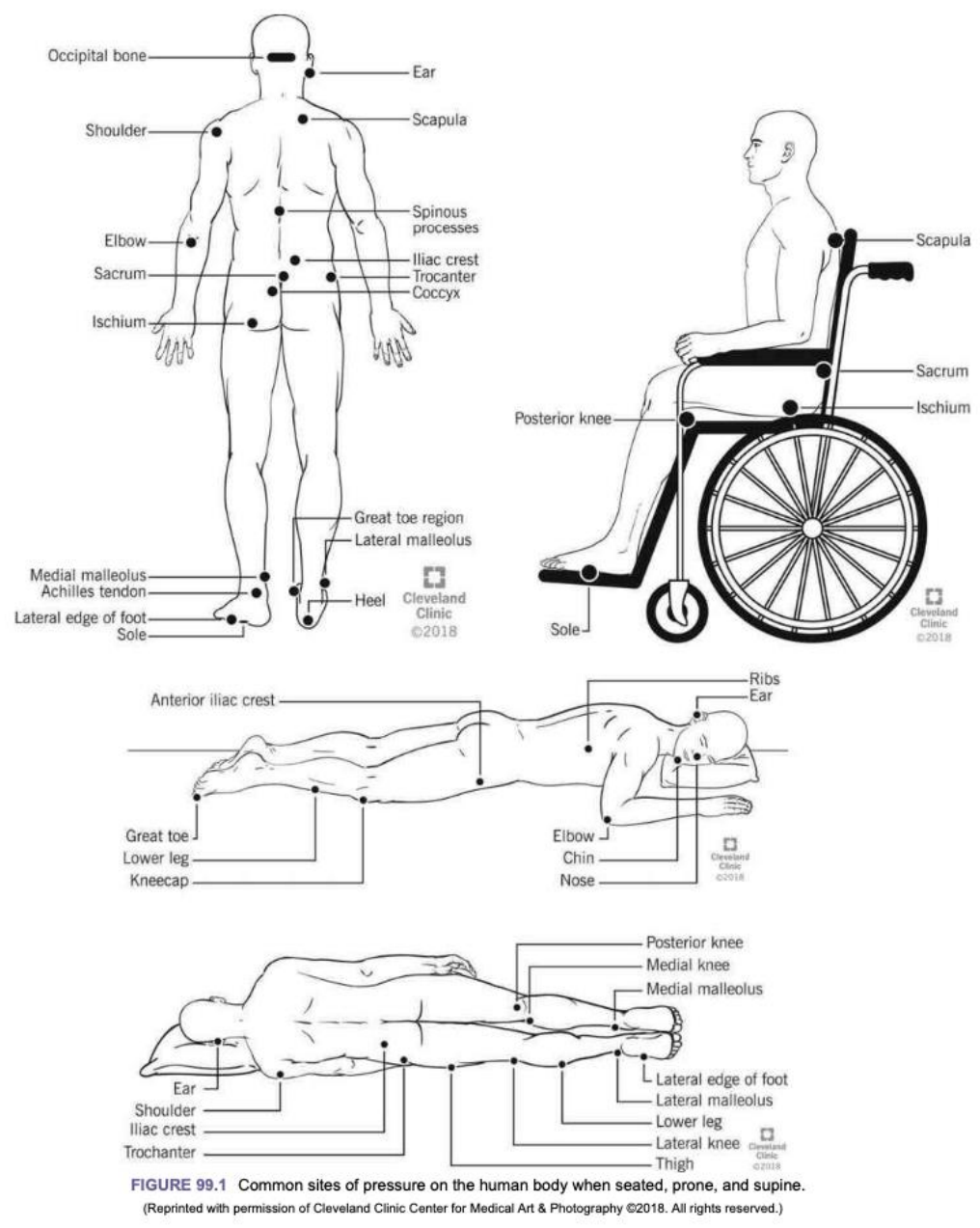

Gambar 1. Lokasi yang sering terjadi penekanan pada tubuh 
Jaringan kulit dapat mempertahankan jumlah tekanan eksternal yang tidak normal, akan tetapi tekanan konstan dalam periode yang cukup lama merupakan penyebab utama dari ulkus dekubitus. Tekanan eksternal harus melebihi tekanan kapiler arteri (32 $\mathrm{mmHg}$ ) untuk menghambat aliran darah dan harus lebih besar dari tekanan penutupan kapiler ( 8 hingga $12 \mathrm{mmHg}$ ) untuk menghambat kembalinya aliran darah dari vena. Jika tekanan di atas nilai tersebut dipertahankan, hal ini akan menyebabkan iskemia pada jaringan tubuh dan lebih lanjut akan mengakibatkan nekrosis jaringan. Tekanan yang cukup besar ini dapat disebabkan oleh kompresi atau tekanan dari kasur yang keras, pagar tempat tidur rumah sakit, atau permukaan keras tempat pasien bersentuhan. Gesekan yang disebabkan oleh kulit yang memiliki kontak langsung dengan permukaan seperti pakaian atau tempat tidur juga dapat menyebabkan timbulnya ulkus yang terjadi pada saat istirahat di lapisan kulit yang superfisial. Kelembaban dapat menyebabkan ulkus dan memperburuk ulkus yang ada melalui kerusakan jaringan dan maserasi.

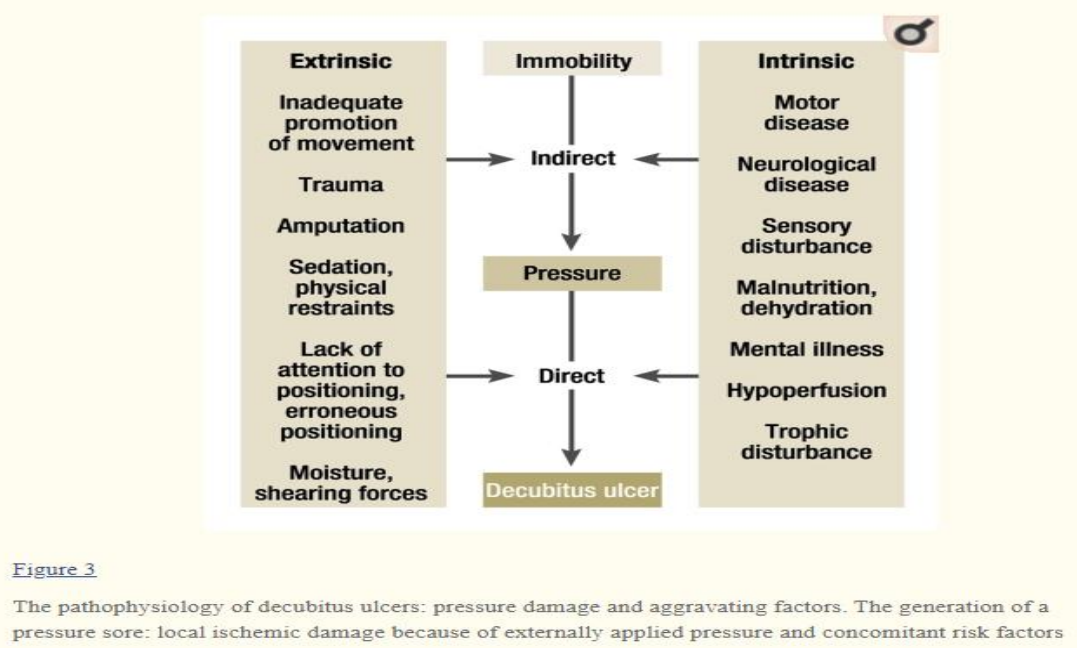

Gambar 2. Patofisilogi Ulkus Dekubitus

\section{Manifestasi Klinis Ulkus Dekubitus}

Menurut NPUAP (National Pressure Ulcers Advisory Panel) 2014, luka tekan dibagi menjadi empat stadium, yaitu:

1. Stadium 1:

a. Adanya perubahan dari kulit yang dapat diobservasi. Apabila dibandingkan dengan kulit yang normal, maka akan tampak salah satu tanda sebagai berikut: perubahan temperatur kulit (lebih dingin atau lebih hangat)

b. Perubahan konsistensi jaringan (lebih keras atau lunak)

c. Perubahan sensasi (gatal atau nyeri)

d. Pada orang yang berkulit putih, luka mungkin kelihatan sebagai kemerahan yang menetap. Sedangkan pada yang berkulit gelap, luka akan kelihatan sebagai warna merah yang menetap, biru atau ungu. 
2. Stadium 2: Hilangnya sebagian lapisan kulit yaitu epidermis atau dermis, atau keduanya. Cirinya adalah lukanya superficial, abrasi, melempuh, atau membentuk lubang yang dangkal.

3. Stadium 3: Hilangnya lapisan kulit secara lengkap, meliputi kerusakan atau nekrosis dari jaringn subkutan atau lebih dalam, tapi tidak sampai pada fascia. Luka terlihat seperti lubang yang dalam.

4. Stadium 4: Hilangnya lapisan kulit secara lengkap dengan kerusakan yang luas, nekrosis jaringan, kerusakan pada otot, tulang atau tendon. Adanya lubang yang dalam serta saluran sinus juga termasuk dalam stadium IV dari luka tekan.

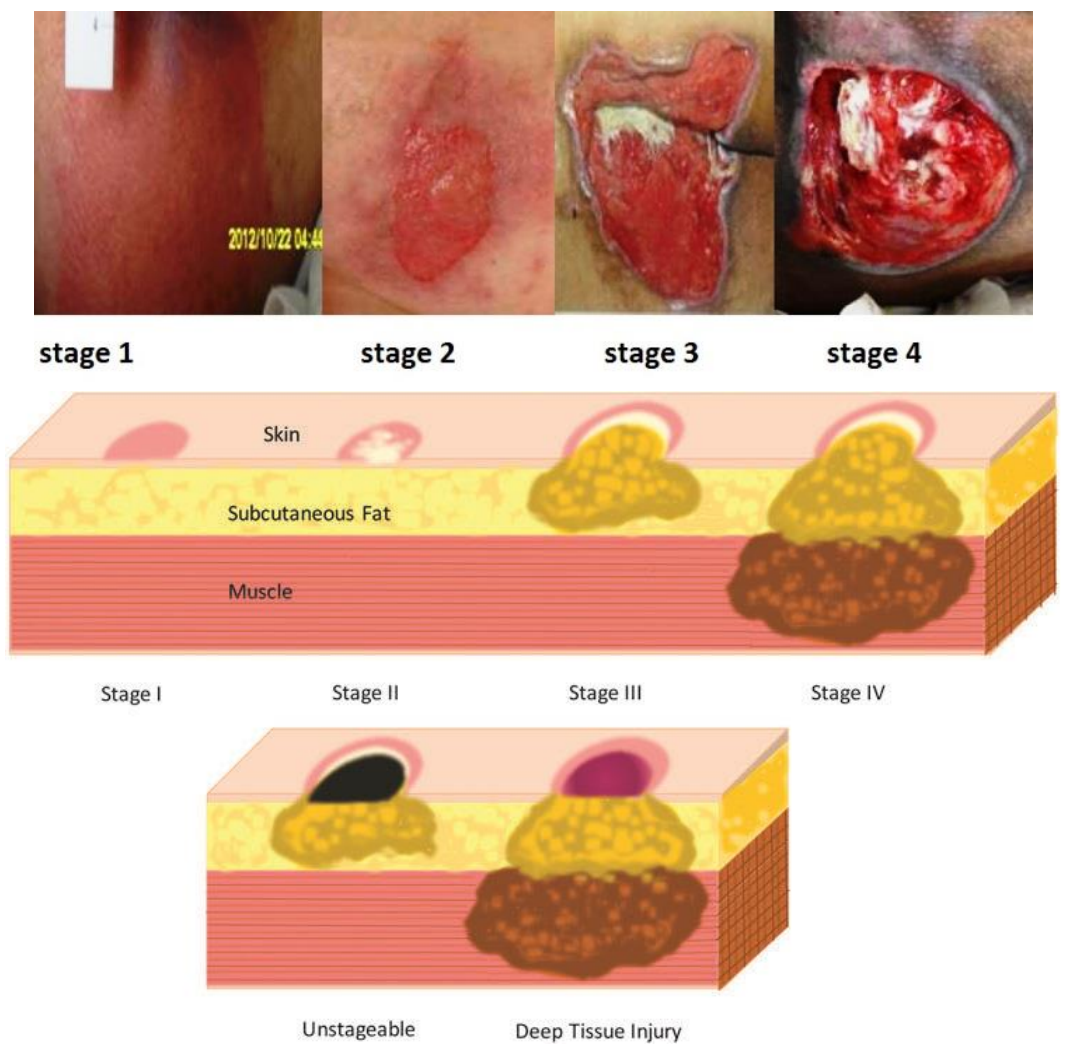

Gambar 3. Stadium Luka Tekan, NPUAP (2014)

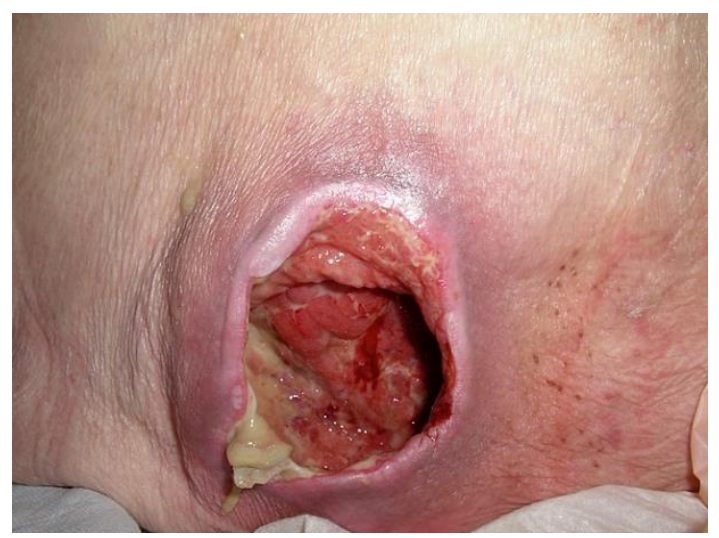

Gambar 4. Gambaran Ulkus Dekubitus Derajat 4 


\section{Definisi, Epidemiologi dan Etiologi Ulkus Diabetikum}

Ulkus diabetikum adalah komplikasi yang sering terjadi pada pasien DM (diabetes melitus) yang tidak terkontrol. Ulkus tersebut dapat terbentuk karena kurang nya kontrol glikemik, neuropati, penyakit pembuluh darah tepi, atau perawatan luka pada kaki yang tidak maksimal. Ulkus tersebut biasanya muncul di area kaki yang sering atau berulang mengalami trauma dan tekanan (Oliver dan Mutluoglu, 2020).

Data epidemiologi menunjukkan estimasi risiko ulkus diabetikum adalah $15 \%$ dari keseluruhan penderita diabetes. Secara global, lebih dari 150 juta penduduk dunia pada tahun 2016 menderita diabetes dan hampir seperempatnya berisiko memiliki ulkus diabetikum. Dua puluh lima persen kasus ulkus diabetikum berdampak pada amputasi organ. Namun, 40\% kasus ulkus diabetikum dapat dicegah dengan rawat luka yang baik. Pada $60 \%$ kasus ulkus diabetikum berkaitan erat dengan neuropati perifer.

Penyebab dari ulkus diabetikum yaitu multifaktorial. Namun, untuk penyebab umum yang mendasari yaitu kurangnya mengontrol kadar glikemik, perawatan luka yang tidak tepat, alas kaki yang tidak pas, neuropati perifer dan sirkulasi buruk, kulit kering, dan lain-lain. Penderita diabetes sekitar 60\% mengalami neuropati yang akhirnya menyebabkan ulkus kaki. Individu yang memiliki kaki tipe rata lebih berisiko untuk timbulnya ulkus karena mereka mengalami stres yang tidak proporsional di seluruh kakinya dan menyebabkan peradangan jaringan di area berisiko tinggi di kaki (Oliver dan Mutluoglu, 2020).

\section{Patofisiologi Ulkus Diabetikum}

Aterosklerosis dan neuropati periferal adalah dua penyebab utama yang menyebabkan komplikasi diabetes. Aterosklerosis menyebabkan penurunan aliran darah dalam pembuluh darah besar sehingga terjadi penebalan pada membran pembuluh darah kapiler, hilangnya elastisitas, dan pengendapan lipid di dalam dinding pembuluh darah. Aterosklerosis jika tidak ditangani dengan cepat akan menyebabkan iskemia pada pembuh darah. Neuropati perifer mempengaruhi sistem saraf sensorik, motorik, dan otonom. Ada penyebab multifaktorial seperti vasa nervorum, disfungsi endotel, hiperosmolaritas kronis, dan efek peningkatan sorbitol dan fruktosa.

\section{Manifestasi Klinis Ulkus Diabetikum}

Tanda dan gejala ulkus diabetikum menurut (ADA, 2010) sebagai berikut:

1. Sering kesemutan

2. Nyeri kaki saat istirahat

3. Sensasi rasa berkurang

4. Kerusakan jaringan (nekrosis)

5. Penurunan denyut nadi arteri dorsalis pedis, tibialis, dan poplitea 
6. Kaki menjadi atrofi, dingin dan kuku menebal

7. Kulit kering

8. Didapatkan luka yang timbul secara spontan maupun karena trauma sehingga menyebabkan luka terbuka yang mampu menghasilkan gas gangren berakibat terjadinya osteomielitis. Gangren kaki merupakan penyebab utama dilakukan amputasi kaki kaki nontraumatik.

Klasifikasi luka kaki diabetik sangat diperlukan untuk menggambarkan luka pasien yang dirawat, mempelajari hasil akhir pasien setelah perawatan serta mendapat pemahaman yang lebih tentang kaki diabetik. Klasifikasi derajat ulkus diabetik dapat dibagi menjadi enam tingkatan menurut sistem Wagner berdasarkan dalamnya luka, derajat infeksi, dan derajat gangrene.

\begin{tabular}{cl}
\hline Derajat & \multicolumn{1}{c}{ Keterangan } \\
\hline 0 & $\begin{array}{l}\text { Belum ada luka terbuka, kulit masih utuh dengan kemungkinan } \\
\text { disertai kelainan bentuk kaki }\end{array}$ \\
\hline 1 & Luka superfisial \\
\hline 2 & $\begin{array}{l}\text { Luka sampai pada tendon atau lapisan subkutan yang lebih } \\
\text { dalam, namun tidak sampai pada tulang }\end{array}$ \\
\hline 3 & Luka yang dalam, dengan selulitis atau formasi abses \\
\hline 4 & $\begin{array}{l}\text { Gangren yang terlokalisir (gangren dari jari-jari atau bagian } \\
\text { depan kaki/forefoot) }\end{array}$ \\
\hline 5 & $\begin{array}{l}\text { Gangren yang meliputi daerah yang lebih luas (sampai pada } \\
\text { daerah lengkung kaki/mid/foot dan belakang kaki/hindfoot) }\end{array}$ \\
\hline
\end{tabular}

Gambar 5. Gambaran Ulkus Diabetikum Neuropati Pada Pasien Diabetes.

Modifikasi dari klasifikasi Wagner adalah Klasifikasi Texas (University of Texas Wound Classification) yang terdiri dari empat derajat dan menilai ada tidaknya infeksi dan atau iskemia. Sistem ini dapat memprediksi outcome dari penderita ulkus diabetik karena meningkatnya derajat ulkus menandakan kesulitan kesembuhan dan meningkatnya resiko amputasi. 
Lalu Muhammad Hafizh Izuddin Alzamani, Mona Rianta Yolanda Marbun, Mutya Eka Purwanti, Rani Salsabilla, Siti Rahmah

\begin{tabular}{lllll} 
& Grade 0 & Grade 1 & Grade 2 & Grade 3 \\
\hline Stage A & $\begin{array}{l}\text { Lesi pre- atau } \\
\text { post- ulserasi } \\
\text { dengan } \\
\text { epitelisasi } \\
\text { sempurna }\end{array}$ & $\begin{array}{l}\text { Luka superfisial, } \\
\text { tidak melibatkan } \\
\text { tendon, kapsul, } \\
\text { atau tulang }\end{array}$ & $\begin{array}{l}\text { Luka } \\
\text { melibatkan } \\
\text { tendon atau } \\
\text { kapsul }\end{array}$ & $\begin{array}{l}\text { Luka } \\
\text { melibatkan } \\
\text { tulang atau } \\
\text { sendi }\end{array}$ \\
& & & \\
\hline Stage B & Infeksi & Infeksi & Infeksi & Infeksi \\
\hline Stage C & Iskemia & Iskemia & Iskemia & Iskemia \\
\hline Stage D & $\begin{array}{l}\text { Infeksi dan } \\
\text { iskemia }\end{array}$ & $\begin{array}{l}\text { Infeksi dan } \\
\text { iskemia }\end{array}$ & $\begin{array}{l}\text { Infeksi dan } \\
\text { iskemia }\end{array}$ & $\begin{array}{l}\text { Infeksi dan } \\
\text { iskemia }\end{array}$ \\
\hline
\end{tabular}

Tabel 2. Klasifikasi University of Texas

\section{Penatalaksanaan Ulkus Kronis}

\section{Manajemen luka menggunakan prinsip TIME}

Luka kronis menjadi 'stuck' pada fase inflamasi dan proliferasi penyembuhan sehingga membuat penyembuhan terhambat. Epidermis gagal bermigrasi melintasi jaringan luka dan terjadi hiperproliferasi di tepi luka yang mengganggu sel normal yang bermigrasi di atas luka. Pada luka kronis terlihat adanya produksi molekul matriks yang berlebihan akibat disfungsi dan disregulasi seluler yang mendasari. Walau kadar faktor pertumbuhan, fibrinogen dan fibrin serta makromolekul scavenge lainnya yang membantu penyembuhan luka, banyak pada luka, namun faktor tersebut dapat terjebak dan tidak bisa melakukan proses penyembukan luka. Pada luka kronis, cairannya berbeda secara biokimia dengan luka akut. Sifat cairannya yaitu memperlambat atau bahkan menghalangi perkembangbiakan sel, seperti keratinosit, fibroklast dan sel endotel, yang penting untuk proses penyembuhan luka (Dowsett and Ayello, 2004).

Luka yang tidak berhasil sembuh pada umumnya disebabkan oleh banyak faktor yang meliputi faktor lokak dan host. Penyebab yang mendasari gagal nya penyembuhan luka perlu diatasi jika ingin berhasil. Persiapan dasar luka adalah cara untuk memfokuskan secara sistematis pada semua komponen penting dari luka yang tidak sembuh untuk mengidentifikasi kemungkinan penyebab masalah. Ini adalah konsep yang menghubungkan pengobatan dengan penyebab luka dengan berfokus pada komponen dari perawatan luka lokal: debridement, keseimbangan bakteri dan keseimbangan kelembaban. Adapun pinsip TIME dari persiapan dasar luka adalah untuk melihat kaitan dari observasi klinsi dan abnormalitas dari sel yang mendasari dan efek dari inntervensi di tingkat seluler. Akronim TIME adalah singkatan dari (Dowsett and Ayello, 2004) :

$\mathrm{T}$ (Tissue): Untuk jaringan yang tidak layak atau sudah tidak baik

I (Infection): Untuk luka yang terdapat infeksi/inflamasi

M (Moisture): Untuk ketidakseimbangan kelembaban luka, yang harus ditangani

$\mathrm{E}(E d g e)$ : Untuk luka yang tepi nya tidak tidak melintasi ke luka 
Tabel 1. Prinsip TIME dari persiapan dasar luka (WBP)

\begin{tabular}{|c|c|c|c|c|}
\hline $\begin{array}{l}\text { KLINIS } \\
\text { OBSERVASI }\end{array}$ & $\begin{array}{l}\text { DIUSULKAN } \\
\text { PATOFISIOLOGI }\end{array}$ & $\begin{array}{l}\text { KLINIS WBP } \\
\text { TINDAKAN }\end{array}$ & $\begin{array}{l}\text { PENGARUH WBP } \\
\text { TINDAKAN }\end{array}$ & HASIL KLINIS \\
\hline $\begin{array}{l}\text { JARINGAN NON-VIABLE } \\
\text { ATAU KURANG }\end{array}$ & $\begin{array}{l}\text { Matriks rusak dan } \\
\text { kerusakan sel } \\
\text { penyembutan }\end{array}$ & $\begin{array}{l}\text { Debridemen (episodik } \\
\text { atau berkelanjutan) } \\
\text { autolitik, tajam } \\
\text { bedah, enzimatik, } \\
\text { mekanis } \\
\text { agen biologis }\end{array}$ & $\begin{array}{l}\text { Pemulihan luka } \\
\text { dasar dan fungsional } \\
\text { matriks ekstraselular } \\
\text { protein }\end{array}$ & Dasar luka yang layak \\
\hline $\begin{array}{l}\text { INFEKSI ATAU } \\
\text { PERADANGAN }\end{array}$ & $\begin{array}{l}\text { Jumlah bakteri tinggi atau } \\
\text { peradangan berkepanjangan } \\
\text { † sitokin inflamasi } \\
\text { † aktivitas protease } \\
\text { † aktivitas faktor pertumbuhan }\end{array}$ & $\begin{array}{l}\text { Hapus fokus yang terinfeksi } \\
\text { Topikal / sistemik } \\
\text { antimikroba } \\
\text { antiradang } \\
\text { penghambatan protease }\end{array}$ & $\begin{array}{l}\text { Jumlah bakteri rendah atau } \\
\text { peradangan terkontrol: } \\
\text { łsitokin inflamasi } \\
\text { łaktivitas protease } \\
\text { † aktivitas faktor pertumbuhan }\end{array}$ & $\begin{array}{l}\text { Keseimbangan bakteri dan } \\
\text { mengurangi peradangan }\end{array}$ \\
\hline $\begin{array}{l}\text { KELEMBAABAN } \\
\text { KETIDAKSEMBAANGAN }\end{array}$ & $\begin{array}{l}\text { Pengeringan melambat } \\
\text { migrasi sel epitel } \\
\text { Penyebab cairan yang berlebihan } \\
\text { maserasi luka } \\
\text { batas }\end{array}$ & $\begin{array}{l}\text { Terapkan kelembaban- } \\
\text { balancing balancing } \\
\text { Kompresi, negatif } \\
\text { tekanan atau lainnya } \\
\text { metode penghapusan } \\
\text { cairan }\end{array}$ & $\begin{array}{l}\text { Migrasi sel epitel yang } \\
\text { dipulihkan, pengeringan } \\
\text { dihindari } \\
\text { Edema, berlebihan } \\
\text { terkontrol cairan, } \\
\text { maserasi dihindari }\end{array}$ & Keseimbangan kelembaban \\
\hline $\begin{array}{l}\text { TEPI LUKA } \\
\text { NON ADVANCING ATAU } \\
\text { UNDERMINED }\end{array}$ & $\begin{array}{l}\text { Tidak bermigrasi } \\
\text { keratinosit } \\
\text { Luka tidak responsif } \\
\text { sel dan kelainan pada } \\
\text { matriks ekstraseluler } \\
\text { atau protease abnormal } \\
\text { aktivitas }\end{array}$ & $\begin{array}{l}\text { Menilai kembali penyebab atau } \\
\text { pertimbangkan korektif } \\
\text { terapi } \\
\text { debridement } \\
\text { cangkok kulit } \\
\text { agen biologis } \\
\text { terapi tambahan }\end{array}$ & $\begin{array}{l}\text { Migrasi keratinosit } \\
\text { dan luka responsif } \\
\text { sel. Pemulihan } \\
\text { protease yang sesuai } \\
\text { Profil }\end{array}$ & $\begin{array}{l}\text { Memajukan tepi } \\
\text { luka }\end{array}$ \\
\hline
\end{tabular}

Tabel 3. Prinsip TIME dari persiapan dasar luka (WBP) sebagai ilustrasi secara sederhana menjelaskan kaitan observasi klinis, abnormalitas seluler, dan efek intervensi di tingkat sel.

\section{T (Tissue): Menangani jaringan yang tidak layak atau non-viable}

Jaringan non-viable, nekrosis atau pengelupasan, menghambat proses penyembuhan luka dan menjadi fokus infeksi. Untuk mendorong pertumbuhan jaringan sehat, maka diperlukan vaskularisasi yang baik. Sehingga membersihkan jaringan yang tidak dapat hidup yang mencegah pertumbuhan jaringan yang baik adalah hal yang penting (Dowsett and Ayello, 2004).

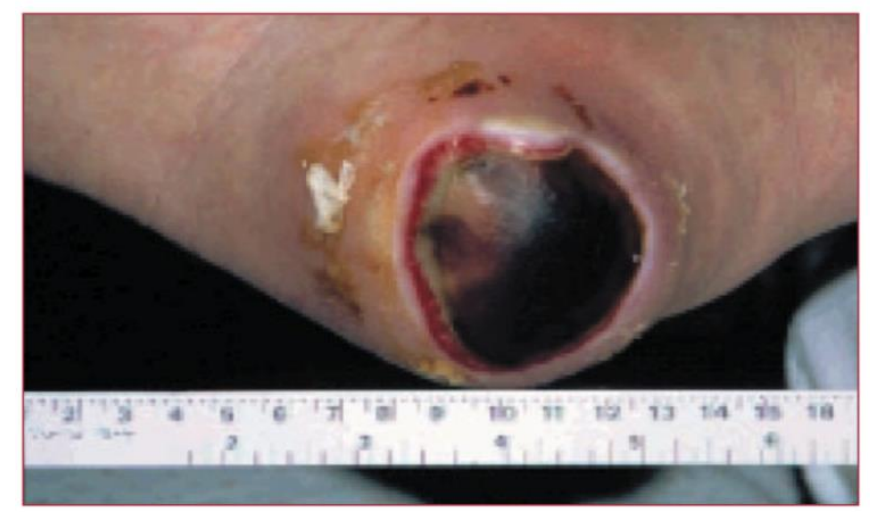

Figure 1. A necrotic wound.

Gambar 6. Ulkus yang Mengalami Nekrosis 
Devitalisasi, jaringan nekrotik rentan terjadinya infeksi, memperpanjang fase inflamasi, secara mekanik menghalangi kontraksi dan menghamabt reepitelisasi. Jika luka terlihat ada jaringan yang tidak layak atau sudah mati, maka metode pembersihan dapat dilakukan dengan tujuan untuk mempercepat penyembuhan dan mengurangi resiko infeksi lokal. Luka kronis cenderung membutuhkan perawatan debridement yang berkelanjutan daripada intervensi tunggal. Debridemen dapat menurunkan kontaminasi pada luka dan menurunkan destruksi jaringan. Ada lima metode debrimen, setiap metode memiliki kelebihan dan kekurangannya, meliputi autolitik, surgikal/tajam, enzimatik, mekanikal, dan biologikal. Metode debridement yang dipilih disesuaikan dengan karakteristik dan preferensi pasien, pengetahun dan kemampuan dari klinisi dan kesediaan bahan. Berikut adalah pertimbangan klinisi dalam memilih metode debridement (Dowsett and Ayello, 2004):

a. Luka: Etiologi, lokasi, seberapa luasa kerusakan jaringannya, jenis jaringan yang terlibat, ukuran dan seberapa luas jaringan yang devitilisasi, jumlah produksi eksudat.

b. Praktek: keahlian klinis dan akuntabilitas profesional, sumber daya yang tersedia, waktu yang tersedia, hemat biaya, keinginan pasien

\section{I (Infection): Resolusi ketidakseimbangan bakteri}

Infeksi pada luka menyebabkan nyeri dan ketidaknyamanan pada pasien, penyembuhan luka yang tertunda dapat mengancam jiwa.

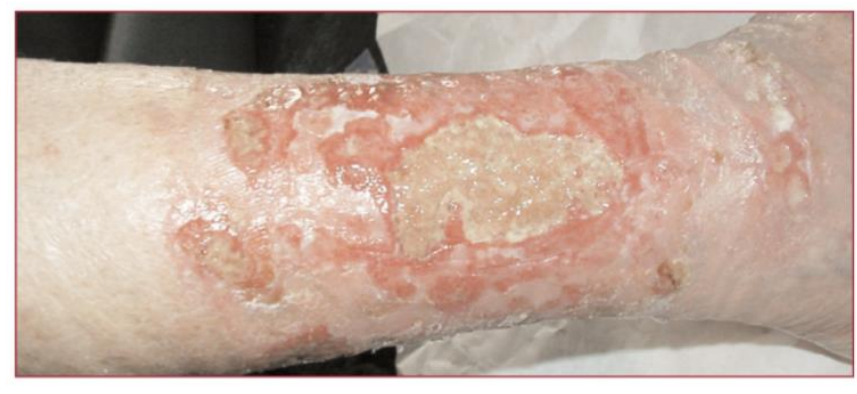

Figure 2. Infected wound.

Gambar 7. Luka yang Terinfeksi

Pada dasarnya di luka terdapat bakteri, jika pada luka kronis terdapat bakteri bukan berarti terjadi infeksi, karena bakteri memproduksi enzim proteolitik (hyaluronidase) yang berkontribusi dalam debridement luka dan menstimulasi neutrofil untuk mengeluarkan protease. Namun, ketika infeksi terjadi pada luka, seperti yang ada di gambar 2, hal tersebut dapat menghambat penyembuhan luka. Keterlibatan bakteri pada luka dapat dibagi menajdi 4 sebagai berikut:

a. Kontaminasi luka: adanya mikro-organisme yang tidak bereplikasi, seperti organisme tanah, pada luka.

b. Kolonisasi luka: adanya mikro-organisme bereplikasi yang tidak menyebabkan cedera pada inang. Ini termasuk komensal kulit, seperti 
Staphylococcus epidermidis dan Corynebacterium spp., Yang dalam banyak keadaan telah terbukti meningkatkan laju penyembuhan luka.

c. Kolonisasi kritis: bakteri menyebabkan keterlambatan dalam penyembuhan luka tanpa adanya infeksi yang nyata.

d. Infeksi luka.

Perawatan pertama-tama harus berfokus pada mengoptimalkan resistensi host, dan kondisi mendasar yang mengurangi imunitas harus ditangani. Antibiotik sistemik belum tentu merupakan cara yang paling tepat untuk mengurangi beban bakteri pada luka, terutama karena adanya ancaman peningkatan resistensi bakteri dan harus digunakan jika infeksi tidak dapat ditangani dengan terapi lokal. Metode lain mungkin lebih cocok dan harus dipertimbangkan terlebih dahulu: debridemen untuk mengangkat jaringan yang rusak; pembersihan luka; dan penggunaan antimikroba topikal, misalnya dressing perak. Sebagai alternatif, studi menunjukkan bahwa beberapa sediaan yodium dan perak memiliki efek bakteriosidal bahkan terhadap organisme multiresisten seperti Staphylococcus aureus yang resisten methicillin (MRSA). Terapi antibiotil sistemik dapat diberikan apabila terdapat tanda infeksi sistemik seperti demam, infeksi yang mengancam jiwa, selulitis yang meluas $>1 \mathrm{~cm}$ melewati margin luka dan struktur dasar infeksi (Dowsett and Ayello, 2004).

\section{M (Moisture): Mengembalikan keseimbangan kelembapan}

Keseimbangan kelembaban dibutuhkan pada penanganan luka untuk mencegah pengeringan dan maserasi. Luka yang terpapar pada lingkungan yang kering dapat terbentuk krusta keras, dan kolagen serta matriks dan jaringan sekitar luka mengering. Keratinosit yang tertimpa dibawah lapisan crusta dan matriks mengakibatkan tidak terjadinya re-epitelisasi yang baik. Pada luka yang terlalu lembab dapat menyebabkan maserasi dari kulit sekitarnya.

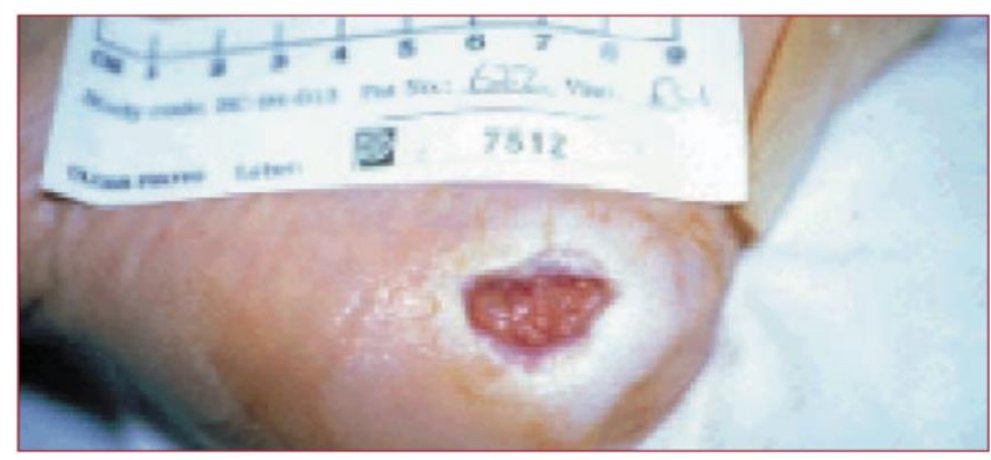

Figure 3. Excessive exudate.

Gambar 8. Luka yang Terdapat Eksudat Berlebih

Manajemen eksudat akan sukses apabila dapat menyeimbangkan kelembaban dari luka. Manajemen eksudat luka secara langsung melibatkan penggunaan perban kompresi, perban yang sangat menyerap atau sistem mekanis berbasis vakum. Saat ini, ada beberapa pilihan dressings yang tersedia 
untuk menyeimbangkan kelembaban luka. Adapun panduan dalam memilih dressings sebagai berikut:
a. Menjaga lingkungan luka yang lembab
b. Menyerap eksudat luka berlebih
c. Menjaga kulit di sekitarnya tetap kering
d. Tidak perlu sering mengganti balutan
e. Mengurangi risiko infeksi dengan memelihara segel dengan luka
f. Nyaman dan dapat diterima oleh pasien

Selain itu, ada maanjemen secara tidak langsung untuk mengurangi eksudat, yaitu cairan luka mungkin disebabkan oleh kolonisasi bakteri yang ekstrim atau mungkin hanya melibatkan pengurangan tekanan atau peninggian anggota tubuh yang terkena (Dowsett and Ayello, 2004).

\section{E (Edge): Luka yang tepinya tidak kunjung menutup atau menyatu}

Ketika tepi luka gagal untuk berpindah atau terjadi kerusakan. Hal tersebut dapat dilihat pada gambar dibawah ini:

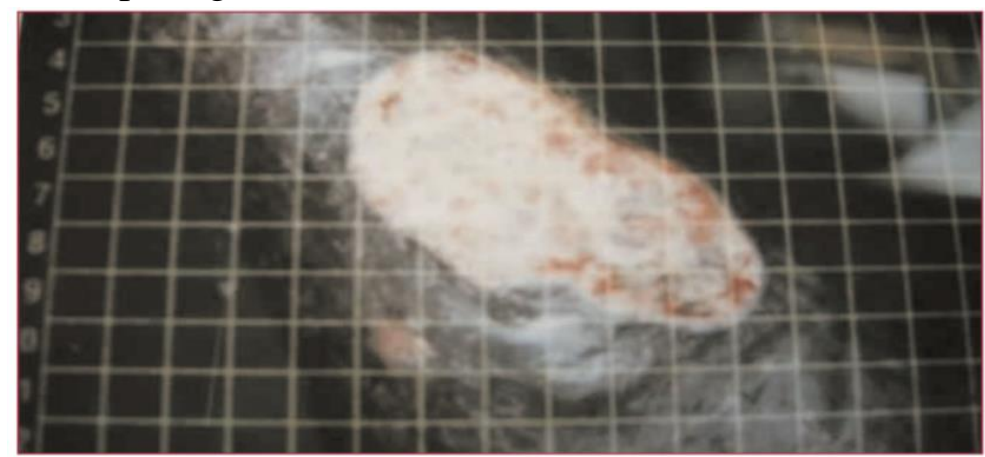

Figure 4. Abnormal edge.

Gambar 9. Tepi Luka yang Abnormal

Pada umumnya ulkus kronis terjadi karena gagal dapat re-epitelisasi dan biasanya diikuti dengan inflamasi yang berkepanjangan. Epidermis gagal untuk bermigrasi melewati luka dan terdapat hiperproliferasi pada margin luka yang menghambat sel normal bermigrasi diatas luka. Jika batasnya rusak, ini mungkin merupakan tanda kolonisasi atau infeksi kritis, dan pada tingkat sel, kurangnya migrasi epidermis dapat disebabkan oleh sel luka yang tidak responsif dan kelainan pada aktivitas protease yang menurunkan matriks ekstraseluler (ECM) segera setelah dibentuk. Penyakit pembuluh darah perifer, diabetes, imobilitas dan malnutrisi, harus dinilai pada awal pengobatan dan dikoreksi sejauh mungkin sebelum intervensi lokal dilakukan. Status kesehatan pasien secara keseluruhan berdampak signifikan pada proses penyembuhan luka. Ada beberapa kondisi dan intervensi yang dapat menghambat proses penyembuhan luka, yaitu:
a. Penggunaan steroid sistemik
b. Penggunaan obat imunosupresif
c. Penggunaan antiradang nonsteroid
d. Artritis rheumatoid 
e. Penyakit autoimun lainnya seperti lupus sistemik, vaskulitis atau pioderma gangrenosum yang tidak terkontrol

f. Gizi yang tidak memadai atau buruk

Jika luka masih gagal sembuh, seperti yang ditunjukkan oleh kegagalan epitelisasi ulang, penting untuk meninjau kembali faktor-faktor ini dan faktor lainnya dan mengambil intervensi lebih lanjut jika perlu (Dowsett and Ayello, 2004).

Pada manajemen ulkus diabetikum, pada derajat awal diberikan penanganan sesuai dengan konsep TIME untuk perwatan luka. Namun, pada beberapa kondisi, dibutuhkan tindakan amputasi. Untuk indikasi ulkus diabetikum yang dilakukan amputasi sebagai berikut (Weledji and Fokam, 2014):

Summary of indications for conservative surgical approach or primary amputation

\begin{tabular}{ll}
\hline \multicolumn{1}{c}{ Debridement/minor amputation } & \multicolumn{1}{c}{ Primary amputation } \\
\hline Good blood supply to foot but infected & wet gangrene (infection + ischaemia) \\
Small vessel disease and gangrenous toes & life-threatening sepsis \\
Successful surgical bypass & extensive muscle necrosis \\
Neuropathic foot with little arterial disease & revascularisation technically impossible, bed-ridden patients/functionally useless limb \\
Osteomyelitis with little arterial disease & \\
\hline
\end{tabular}

Tabel 4. Indikasi Tindakan Amputasi Primer

\section{Kesimpulan}

Ulkus kronis merupakan gangguan jaringan kulit yang berlangsung lama dan menjadi penyebab utama morbiditas dan mortalitas dengan prevalensi yang meningkat. Prevalensi ulkus kronis meningkat karena peningkatan populasi yang menua dan faktor risiko seperti diabetes dan obesitas. Ulkus kronis disebabkan oleh berbagai penyakit termasuk disfungsi vena, diabetes mellitus, infeksi, neuropati perifer, tekanan, dan aterosklerosis.

Ulkus dekubitus dan ulkus diabetikum merupakan ulkus kronis yang disebabkan oleh tekanan dan diabetes melitus. Ulkus dekubitus disebabkan oleh tekanan mekanis yang tidak dapat dihilangkan ke jaringan lunak, paling sering terjadi pada tulang yang menonjol seperti sakrum, iskium, tumit, atau trokanter. Jaringan kulit dapat mempertahankan jumlah tekanan eksternal yang tidak normal, akan tetapi tekanan konstan dalam periode yang cukup lama merupakan penyebab utama dari ulkus dekubitus. Ulkus dekubitus sendiri dibagi menjadi 4 stadium, yang dimana masing masing stadium menggambarkan kondisi klinisi kerusakan jaringan yang terjadi. Ulkus diabetikum sendiri dapat terbentuk karena kurang nya kontrol glikemik, neuropati, penyakit pembuluh darah tepi, atau perawatan luka pada kaki yang tidak maksimal. 
Lalu Muhammad Hafizh Izuddin Alzamani, Mona Rianta Yolanda Marbun, Mutya Eka Purwanti, Rani Salsabilla, Siti Rahmah

\section{BIBLIOGRAFI}

ADA (American Diabetes Association). (2010). Diagnosis and Classification of Diabetes Mellitus. Diabetes Care, 33, 62-90. Google Scholar

Badan Penelitian dan Pengembangan Kesehatan. (2013). Laporan hasil riset kesehatan dasar tahun 2013. Jakarta: Kementerian Kesehatan. Google Scholar

Bansal C, Scott R, Stewart D, Cockerell CJ. (2015) Decubitus ulcers: a review of the literature. Int J Dermatol. 44(10):805-10. Google Scholar

Busch, CH., Aschermann, I., Mnich, C. Hd., (2017). Treatment of Chronic Ulcers. [pdf] Accessed on Google Scholar

Chung, Kevin C. (2020). Grabb and Smith's plastic Surgery $8^{\text {th }}$ ed. Philadelphia : Wolters Kluwer. Google Scholar

Dowsett, C., \& Ayello, E. (2004). TIME principles of chronic wound bed preparation and treatment. British journal of nursing (Mark Allen Publishing), 13(15), S16-S23. Google Scholar

National Pressure Ulcer Advisory Panel. Pressure ulcers: incidence, economics, risk assessment. Consensus Development Conference Statement. (1989) Google Scholar

Oliver TI, Mutluoglu M. (2020). Diabetic Foot Ulcer. In: StatPearls [Internet]. Treasure Island (FL): StatPearls Publishing. Google Scholar

Packer CF, Ali SA, Manna B. (2020). Diabetic Ulcer. In: StatPearls [Internet]. Treasure Island (FL): StatPearls Publishing. Google Scholar

Pranarka K. (2015) Dekubitus. Buku Ajar Boedhi Darmojo Geriatri (Ilmu Kesehatan Usia Lanjut). Jakarta: Badan Penerbit FKUI. P306-18. Google Scholar

Purwanti OS. (2013). Analisis faktor-faktor risiko terjadi ulkus kaki pada pasien diabetes mellitus di RSUD DR. Moewardi [thesis]. Depok: Universitas Indonesia. Google Scholar

Roza RL, Afriant R, Edward Z. (2015). Faktor risiko terjadinya ulkus diabetikum pada pasien diabetes mellitus yang dirawat jalan dan inap di RSUP Dr. M. Djamil dan RSI Ibnu Sina Padang. Jurnal Kesehatan Andalas. 4(1): 243-248.) Google Scholar

Weledji, Elroy P., Fokam, Pius. (2014). Treatment of the diabetic foot - to amputate or not. BMC Surg. 2014; 14: 83. Google Scholar

Zaidi SRH, Sharma S. (2021). Decubitus Ulcer. In: StatPearls [Internet]. Treasure Island (FL): StatPearls Publishing. Google Scholar

First publication right:

Jurnal Syntax Fusion: Jurnal Nasional Indonesia

This article is licensed under:

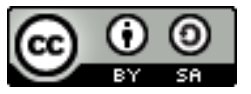

